Hagyományok és kihívások V. Múlt és jövő. Országos Könyvtárszakmai Nap, 2016.

Szerk. Szabó Panna, Székelyné Török Tünde.

Budapest, ELTE Egyetemi Könyvtár és Levéltár. 2017. 99-109.

\title{
Pauler Tivadar jogi szakkönyvtárának 1872-es katalógusa ${ }^{1}$
}

Pauler Tivadar egyetemi tanár, vallás- és közoktatásügyi, majd kétszer igazságügy miniszter és a Magyar Tudományos Akadémia tagja volt. A 19. század második felének meghatározó jogásza, élete és munkássága viszonylag jól feltárt, ${ }^{2}$ noha az Országos Széchényi Könyvtár Kézirattárában őrzött, mintegy 800 fólió terjedelmü, 1845-től haláláig vezetett naplója máig kiadatlan. ${ }^{3}$ Lelkes és elkötelezett könyvgyüjtö lévén könyvtárában ritka és értékes müvek voltak, amelynek katalógusa fennmaradt az ELTE Egyetemi Könyvtár Kézirattárában őrzött hagyatékának dokumentumai és személyes tárgyai között. A több mint ezerhatszáz tételes katalógus 1872-ben készült, amikor Pauler ötvenhat éves volt. A gyüjtemény föleg jogi szakirodalomból áll, de mutatja tulajdonosa érdeklődését a történelem, az irodalom, a vallás és az utazás iránt is. Nagyon fontos figyelembe venni, hogy ez egy müködő, funkcionális könyvtár volt, napi munkájához használta ezeket Pauler.

A Pauler család hagyatékának katalógusát 2004-ben készítettem el az ELTE Egyetemi Könyvtárban, amely azóta online hozzáférhető a könyvtár honlapján pdf formátumban. ${ }^{4}$ Akkor vettem kézbe számos családi ereklyét, például Pauler Tivadar tízéves korában készített gimnáziumi írásgyakorlatát (1. kép), 1861-es fényképét (2. kép), névjegyét, gyászjelentését, felesége, Deréky Sarolta hajtincsét. Akkor írtam le az 1872-es könyvtárkatalógusát, a címleírások azonosításával

${ }^{1}$ Az előadás angol változata elhangzott a „Knižnica ako fenomén kultúry a vzdelanosti. / Libraries as Phenomenon of Culture and Erudition" című konferencián. Martin, Literárne múzeum SNK, 2016. május 11-13.

${ }^{2}$ Ld. pl.: Szabadfalvi József: Pauler Tivadar, az észjogtudomány utolsó nagy alakja. $=$ Zempléni Múzsa, 14. évf. 2014. 2. sz. 12-18. p.; Estók József: A magyar börtönügy arcképcsarnoka: Pauler Tivadar (1816-1886). = Börtönügyi Szemle, 28. évf. 2009. 4. sz. 69-74. p.; P. Miklós Tamás: Adalékok Pauler Tivadar (1816-1886) pályafutásához. = Comitatus, 8. évf. 1998. 3. sz. 62-70 p.; Felkai László: Pauler Tivadar, a közoktatásügyi miniszter. = Pedagógiai Szemle, 37. évf. 1987. 1. sz. $50-58$ p.

${ }^{3}$ Quart. Hung. 2611/1. 355 f., 2611/2. 429 f. A Zágrábban 1844. december 31-én éjjel 3/4 12-kor kelt első bejegyzés tanúsága szerint: „Jelen soroknak czélja nem egy rendes naplónak vezetése, hanem egyedül azon események feljegyzése, mellyeket vagy családi vagy pedig egyéb tekinteteknél fogva a 'feledékenység' örvényéből megmentendőknek találnék. - Sok enyészik az emberi emlékező tehetségéből, mit megtartani tanácsos szükséges volna, ezt tehát megakadályoztatni kivánságom szándékom. - Legyenek évek mulva jelen lapok segédszerül emlékezetemnek; - foglaljanak magukba sok örvendetest, sok jót; kevés szomorítót.” „Egyedül saját használatomra” Pauler naponta átlag 3-5 sort írt naplójába: feljegyezte, milyen az időjárás, mit dolgozott, kikkel találkozott. 1933-ban került a Magyar Nemzeti Múzeum Könyvtár Kézirattárába.

${ }^{4}$ NKA, pályázati azonosító 2120/0229. http://www.konyvtar.elte.hu/regi/kincseink/kezirat/ pauler.htm [2015.06.24.] 
azonban nem foglalkoztam. Amikor elkezdtem azonosítani az egyes tételeket, jó néhány elírást találtam a tíz évvel ezelőtt készített listámban.

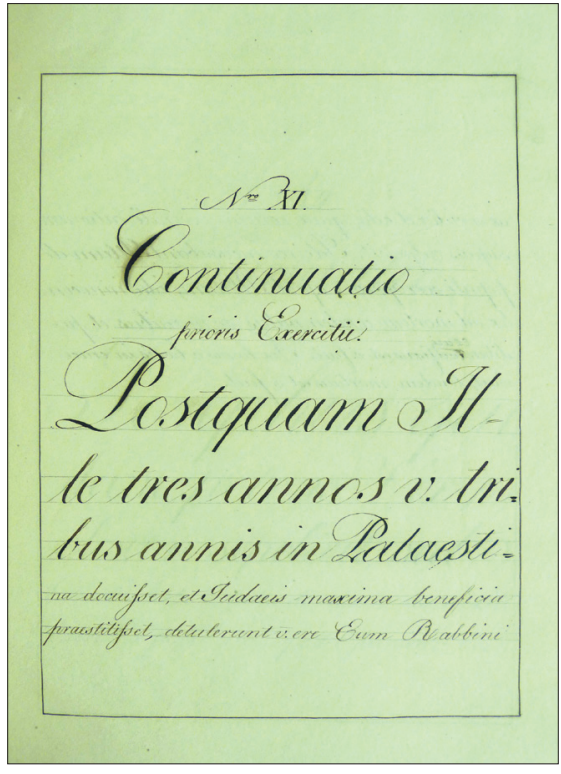

1. kép. Pauler Tivadar tízéves korában készített gimnáziumi írásgyakorlata

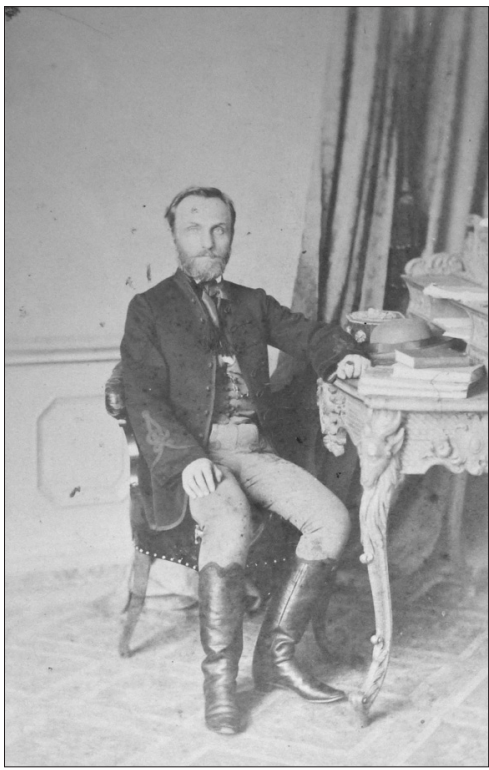

2. kép. Pauler Tivadar 1861-es fényképe

A kéziratos katalógus 1620 tételt tartalmaz. Minden tétel külön kartonon van, és a kartonok a szerző vagy a mücím betürendjében hat mappába vannak bekötve (3. kép). A katalógust egy kéz írta, a könyvtár 1872-es állapotát tükrözi, nincsenek benne későbbi mủvek. A katalóguscédulákon található tételek két részből állnak: 1. az elhelyezést mutató szám- és betűtagból álló kombináció, 2. maga a bibliográfiai leírás (4. kép). Munkám során kíváncsi voltam, vajon milyen lehetett a számés betütagból álló kombinációból adódó csoportosítás. Azt feltételeztem, hogy kirajzolódik valamiféle tematikus rendszer. Úgy gondoltam, hogy ez a csoportosítás betekintést enged a könyvtár elrendezésébe és tulajdonosa gondolkodásmódjába. Hipotézisem azonban nem nyert megerősítést, mert egyes egységekben nagyon különbözö tematikájú müvek kerültek, például az I. A. kategóriában van Berzsenyi Dániel összes müvei, Török János Magyarország Primása címü könyve, a Törvénykezési Lapok 1857-es kötete és Zalka János Szentek Élete címü munkája. Más egységek viszont homogéneknek tünnek, például az I. B. kategóriában kizárólag jogi művek szerepelnek. A II. C. kategóriában a természetjog dominál. Az I. D. kategóriába két folyóirat tartozik, az Uj Magyar Muzeum 1850-1859 között megjelent 18 kötete és a Magyar Akadémiai Értesitő 1847-1862 közötti 16 kötete. A legtöbb szabadkőműves munka az I. H. kategóriában van. 


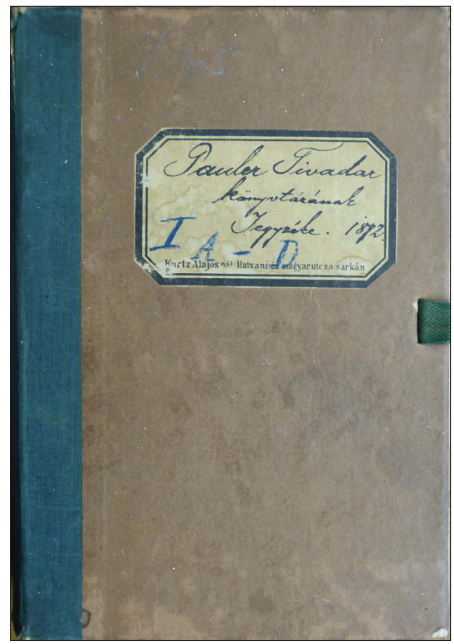

3. kép. A kéziratos katalógus első mappája

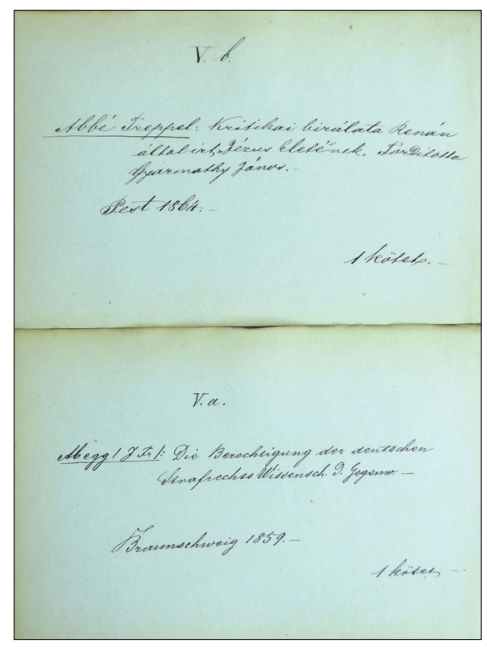

4. kép. Két katalóguscédula

Nemcsak a katalógus, hanem a könyvállomány egy része is megvan az ELTE Egyetemi Könyvtárban és más magyarországi egyetemi könyvtárakban. Az ELTE Egyetemi Könyvtárban található kötetek azonosítása nem egyszerü: egyesekben Pauler saját kezü, fekete tintával írt possessor bejegyzését találtam (5. kép), másokban pedig a feltehetően a könyvtárba kerüléskor beírt ceruzás „Pauler” bejegyzés olvasható (6. kép). Némely kötet korábbi tulajdonosa Zelenay János József, a nagyszombati egyetem jogi karának tanára (164., 1420., 7. kép). Más könyvek korábban a nagyszombati jezsuita kollégium tulajdonát képezték (237., 8. kép). Egy könyv korábbi tulajdonosa Caspar Gilbert Mellerstad stettfeldi plébános volt (141., 9. kép).

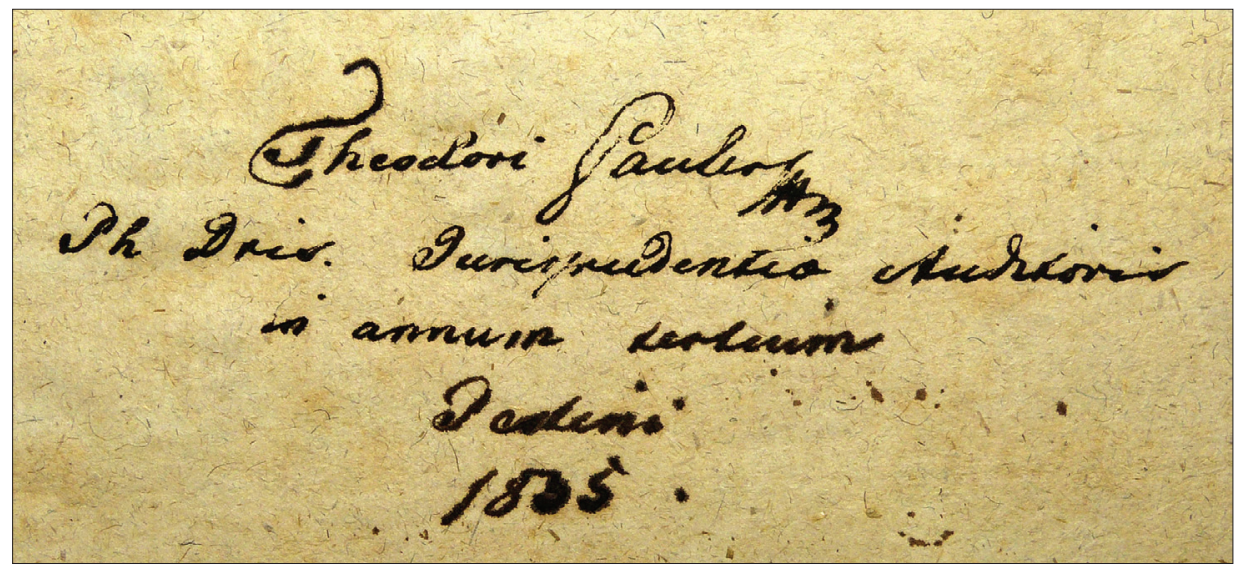

5. kép. Pauler saját kezü, fekete tintával írt possessor bejegyzése 


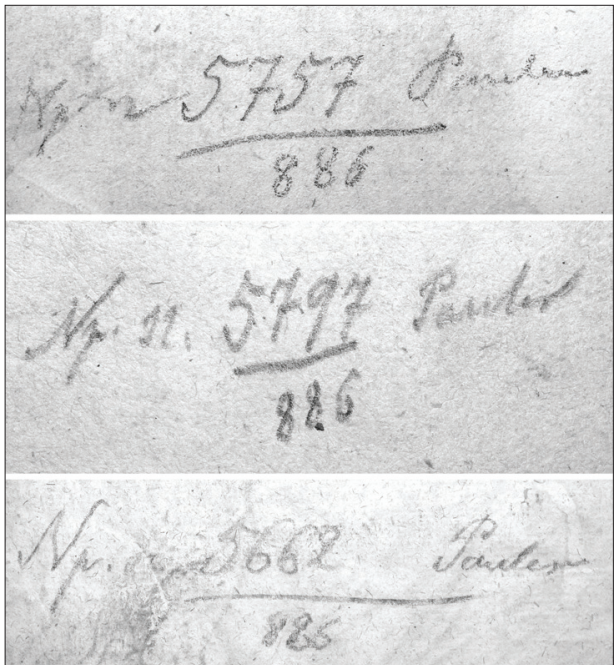

6. kép. Ceruzás „Pauler” bejegyzés

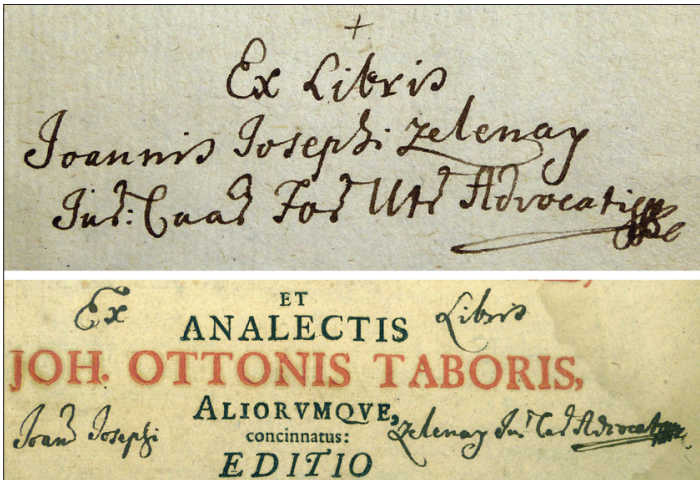

7. kép. Zelenay János József, korábbi tulajdonos gyüjteményéből

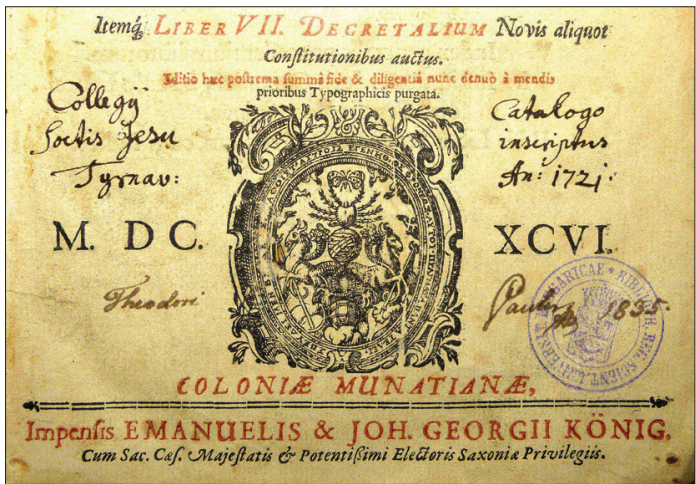

8. kép. A nagyszombati jezsuita kollégium egykori gyüjteményéből 


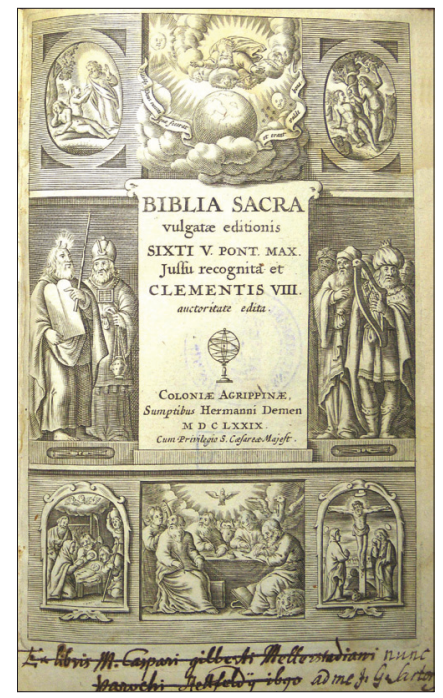

9. kép. Caspar Gilbert Mellerstad stettfeldi plébános, korábbi tuljadonos gyüjteményéböl

További köteteket a „Pauler Tivadaré” bélyegzőcímke azonosít a pécsi, a szegedi és a debreceni egyetemi könyvtárakban. Négy mü például a Pécsi Tudományegyetem Egyetemi Könyvtár és Tudásközpontban található, ahova a „Tudomány- és Müegyetemi Olvasókör'-ből került: 1. Ludwig Ross Wanderung in Griechenland (1169.), 2. Schwartner Márton Statistik des Königreichs Ungern (1276.), 3. Johann Springer Statistik des österreichischen Kaiserstaates (1308.), 4. Julius Franz Schneller Staaten-Geschichte (1249.) címü müve. Egy háromkötetes kiadvány, Szibenliszt Mihály Institutiones juris privati Romani-ja (1376.) pedig a Szegedi Tudományegyetem Könyvtárában van. Az 1872-es katalógusban nem szereplö, ezután megjelent vagy beszerzett müvek is találhatók Pauler Tivadar possessor bejegyzésével magyarországi egyetemi könyvtárakban. Ilyen például Plósz Sándor A keresetjogról címü 1876-ban megjelent munkájának Pauler Tivadar pecsétjével és margináliáival ellátott példánya a Debreceni Egyetemi Könyvtárban. Így ezek a müvek ma is tanulmányozhatók, például a könyvészeti kutatások számára, elsősorban a possessor bejegyzések és margináliák szempontjából. Az állomány vizsgálatára eddig nem került sor, munkám során igyekeztem azonosítani és kézbe venni minél több könyvet.

A lista alapján elmondható, hogy Pauler elsőrangú jogi szakkönyvtárat állított össze, amely korának fontos szakmunkáit is tartalmazta. A könyveknek körülbelül kétharmada latin és német nyelvü, a többi magyar és francia. A müvek időbeli eloszlása a következő: 17 könyv származik a 17. századból, ezek jogi és irodalmi müvek. A legkorábbi könyv a francia jogász és filozófus Jean Bodin 1576-ban írt De republica című müvének 1609-es frankfurti kiadása (164.), ezt 
követi Justinianus Institutiojának egy 1622-es kötheni (53.) és egy 1677-es salzburgi kiadása (616.). Van köztük egy Kölnben 1679-ben kiadott Biblia (141.), továbbá antik (Valerius Maximus (1498.) és Ovidius (1015.)), reneszánsz (pl. Joannes Leo Africanus (17.), Justus Lipsius (618.) és Machiavelli (835.)) és barokk írók (pl. Johann Ferdinand Behamb (112.) és Milton (928.)) müvei. A többi könyv körülbelül fele-fele arányban származik a 18. és a 19. századból.

Mint általában a 18-19. századi könyvtárakban, ${ }^{5}$ Paulerében is megtalálható a görög és a latin klasszikusok egy része, különösen az ekkor még tankönyvként használt Marcus Tullius Cicero szerepel sok, pontosan négy mủvével (217-220.), Horatius három (589-591.), Ovidius két (1014-1015.), Sokrates két (1293-1294.), Homeros (588.), Aristoteles (64.), Julius Caesar (203.), Sallustius Crispus (1201.), Seneca (1282.) és Martialis (885.) egy-egy könyvvel van jelen többnyire latin eredetiben, esetleg német vagy magyar fordításban. A Biblia négy kiadása szerepel a könyvtárban: 1. a legkorábbi a már említett 1679-es kölni kiadás (141., 9. kép), 2. a Dietenberger-Biblia utolsó, 1776-os augsburgi kiadása (301.), 3. a Káldi György-féle magyar fordítás Tárkányi B. József átdolgozásával az 1865-ös egri kiadásban (1368.), 4. az evangélikus tanár Kámory Sámuel fordításának második, 1870-es pesti kiadása (669.). Ezen kívül a magyar állam müködésével kapcsolatos, többnyire jogi és országgyülési dokumentumok, statisztikák, vallási és egyháztörténeti tárgyú kötetek, a magyar történelem középkori és újkori szerzői (Anonymus, Pray György).

Ugyanakkor számtalan egyedi vonás is megfigyelhető. Például erőteljes szabadkőmüves érdeklődésre vallanak egyes tételek (48., 138., 404., 411., 429., 722.,

${ }^{5}$ Vö. pl. Buda Attila: A Károlyiak fóti könyvtára. = Szabolcs-Szatmár-Beregi levéltári évkönyv, XVII. Szerk.: Galambos Sándor, Kujbusné Mecsei Éva. Nyíregyháza, Szabolcs-Szatmár-Bereg Megyei Önkormányzat Levéltára, 2006. 535-548. p.; Csorba György: Kmety György könyvhagyatéka a Magyar Tudományos Akadémia Könyvtárában. = Hadtörténelmi Közlemények, 126. évf. 2013. 3. sz. 839-853. p.; Gángó Gábor: Eötvös József könyvtára. Budapest, Argumentum, 1995.; Granasztói Olga: Olvasótól - olvasóig. Észrevételek a magyar olvasástörténeti kutatások aktuális kérdéseihez. $=$ Korall, 12. évf. 2011. 43. sz. 5-24. p.; Gyáni Gábor: Az olvasó táblabíró. Középosztályi müveltség a 19. század végén. = Történelmi Szemle, 41. évf. 1999. 3-4. sz. 387-403. p.; Hudi József: Könyv és társadalom. Könyvkultúra és müvelődés a XVIII-XX. századi Veszprém megyében. Budapest, Gondolat. 2009.; Halmos Károly-Sebők Richárd: Hild József könyvtára. Rövid ismertetés és konkordancia. = Tanulmányok Budapest Múltjából, 38. Budapest, BTM. 2013. 57-114. p.; Kocsis Éva: Mátyás Flórián, Pécs első akadémikusának könyvtára. $=$ Rangos famíliák -jeles személyek a 18-20. századi Dél-Dunántúlon. Baranyai Történelmi Közlemények, 6. Szerk. Kult László, Ódor Imre. Pécs, Magyar Nemzeti Levéltár Baranya Megyei Levéltára, 2014. 215-244. p.; Marótzy Katalin: Wéber Antal könyvtára. Adalékok a XIX. századi építészeti szakirodalom kutatásához. = Építés-Építészettudomány, 34. évf, 2006. 1-2. sz. 87-112. p.; Perényi Roland: Mit olvas a pesti polgár? Kísérlet a Janny család könyvtárának rekonstrukciójára. = Tanulmányok Budapest Múltjából, 33. Budapest, BTM. 2007. 59-70. p.; Szabó G. Zoltán: Kölcsey Ferenc könyvtára és olvasmányai. Budapest, Országos Széchényi Könyvtár, Gondolat Kiadó. 2009.; Vörös Károly: Egy győri nemes könyvtára a forradalom előtt. Adalék reformkori általános müveltségünk történetéhez. = Magyar Könyvszemle, 71. évf. 1955. 1-2. sz. 72-87. p. 
813., 1114., 1514-1515.). Ezek között találjuk például 1. a közgazdász, ügyvéd majd nyomdatulajdonos Jean-Pierre-Louis Beyerlé Versuch über die Freimaurerei címü müvét (1514.); 2. a fiatalon a „felvilágosodás” szolgálatába állt, majd mélyen vallásossá vált protestáns teológus, Paul Joachim Siegmund Vogel Briefen die Freimaurerei betreffend című kiadványát (411.); 3. a skót James Anderson által írt kétkötetes Szabadkömüves alkotmányt (48., 722.); 4. a több magyarországi páholy alapítójának, Ludwig Lewis-nak a Geschichte der Freimaurerei in Österreich címü müvét (813.); 5. a német Karl August Ragotzky Unterhaltungen für denkender Freymaurer címü kötetét (1114.); és 6. a Betbuch für Freymaurert (138.).

A katalógus tételei között számos, kifejezetten katolikus mủ található. A Biblia négy kiadásán kívül öt, szentek életét bemutató könyv, legendárium szerepel: 1. a Zalka János püspök és Zsihovics Ferenc kanonok által írt Szentek élete több kötete az 1850-es és 1860-as évekből (1602., 1616-1617.); 2. a francia publicista, történész, Charles Forbes Montalembert gróf 1836-ban írt első történelmi könyve a Magyar Szent Erzsébet történetéről, ami magyar fordításban 1862-ben Egerben jelent meg (944.); 3. az irodalomtörténész Toldy Ferenc két nyelvemlékkiadását birtokolta Pauler 1858-1859-ből: a Magyar szentek legendái a Carthausi Névtelentöl és A Debreczeni legendáskönyv a Krisztina-legendával együtt (1445., 1453.). Az I. Rákóczi Ferencről elnevezett Officium Rákóczianum című imádságoskönyvnek egy késői, 1825-ben Budán nyomott kiadásából két példány is megvolt a könyvtárban (992.). ${ }^{6}$ Egyetemes egyháztörténetet tárgyaló munkák is megtalálhatók a gyüjteményében, pl. a tridenti zsinatról (1196.) és két mủ a jezsuita rendtörténetről (440., 1587.).

A könyvtár fö tematikája a jog. Hét mü foglalkozik a római joggal (53. 186., 509., 576., 1010., 1376-1377.), köztük Justinianus már fentebb említett Institutioinak két kiadása, egy latinul és a jogász Hoffmann Pál 1864-ben megjelent magyar fordítása. A magyar szokásjog alapmủve, Werbőczy István Hármaskönyve két, 19. század közepi magyar kiadásban (1519-1520.), a Szónoklattan címü 1870-es Werböczy-kivonatban (1521.) és Okolicsányi János 1648-as lőcsei kiadásában (994.) szerepelt a könyvtárban. A könyvkatalógusban megtaláljuk a 16. század második felének neves francia politikai gondolkodója, Jean Bodin (164.), a 17. századi németalföldi jogász Hugo Grotius (607-608., 668.) és az ugyancsak 17. századi német jogász, politikai gondolkodó Samuel Puffendorf mủveit (538., 1098., 1178.). Az ELTE Egyetemi Könyvtár állományában azonosítottam a katalógusban 237. szám alatt szereplö, 1696-os kiadású Corpus juris Canonici példányát. Ez a könyv 1835-ben került Pauler tulajdonába, és feltehetően hozzá kapcsolható a fejezetkezdetek jelzése a hosszmetszésen (10. kép).

\footnotetext{
${ }^{6}$ Knapp Éva: Officium Rákóczianum. Az I. Rákóczi Ferencről elnevezett imádságoskönyv története és nyomtatott kiadásai. Budapest, Borda. 2000. 95. tétel.
} 


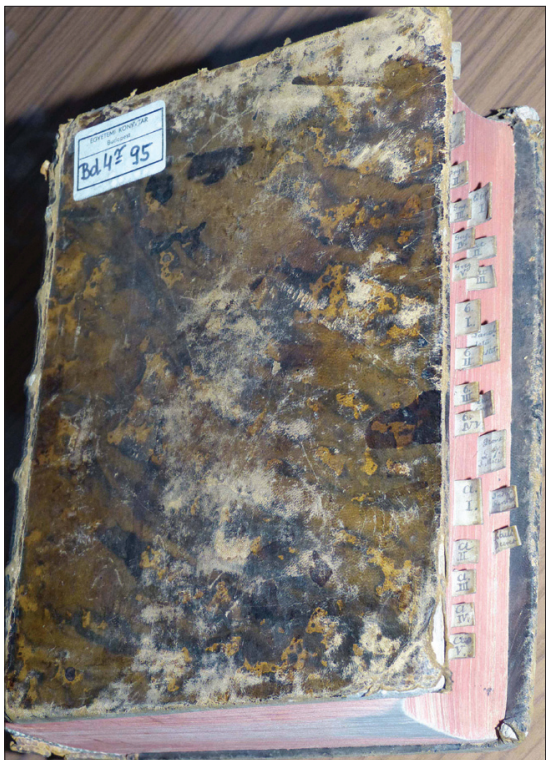

10. kép. Az 1696-os kiadású Corpus juris Canonici

A jogi irányultság mellett bizonyos természettudományok iránti érdeklődés is megfigyelhetö. Ezt Georges-Louis Leclerc Buffon Allgemeine Naturgeschichte (190.), két gimnáziumi tankönyv: Lutter Nándor Ferdinánd A természettan alaprajzának 2. javított és bővített kiadása 1853-ból (831.) és Szabó Ignác Természettani Földrajz (1350.) című művei mutatják. A különféle útikönyveket, várostérképeket és útleírásokat Pauler bel- és külföldi utazásaihoz szerezhette be és használta: 1. egy térkép van Graz-ról (1071.), kettő Bécsről (984., 1072.); 2. Freund Henrik orvos Harkány fürdőhellyel foglalkozó könyve 1871-ből (413.); 3. a Lloyd illusztrált útikönyvsorozatának a Bécstől Triesztig tartó utazást bemutató negyedik kötete (1500.); 4. a német ásványkutató, geológus Johann Gottlieb Lehmann Pozsonytól Nagyszebenig tartó útjának leírása (806.); és 5. a német régész és filológus, Ludwig Ross Wanderung in Griechenland címü müve (1169.).

A könyvtárból teljesen hiányoznak az orientalizmus és az egzotikum iránti érdeklődésre utaló müvek. Jelen vannak viszont a magyar nyelv és a magyarság eredetének kérdésével foglalkozó munkák: 1. az evangélikus lelkész, szabadkőműves Fessler Ignác Aurél 1794-ben Attila hun királyról írt művének 1809es német kiadása (392.); 2. a csehországi káplán és író Wilhelm Gärtner Attila címü, ötfelvonásos tragédiája (437.); 3. a katolikus pap, egyházi és történetíró, armenológus Lukácsy Kristóf $A$ magyarok öselei hajdankori nevei és lakhelyei eredeti örmény kútfők után címü 1870-es könyve (828.); és 4. a katolikus plébános Pátkai Seidel Pál A magyarok története címü 1872-es kötete (1281.). 
Nagyszámú és változatos a lexikon- és enciklopédiairodalom a könyvtárban. Ezeket valószínüleg általános segédletekként használta. A statisztika műveit is megszerezte Pauler, köztük a tudományág első hazai képviselőjének munkáját, Schwartner Márton Statistik des Königreichs Ungarn címü 1809-es, második, budai kiadását (1276.). ${ }^{7}$ A pszichológia egyik előfutára, a német filozófus Friedrich August Carus két könyve is megvolt a könyvtárban (209-210.). A neveléstörténettel és a magyarországi egyetemtörténettel foglalkozó mủvek is szép számban szerepelnek (232., 805., 1314.), például Kazy Ferencnek a nagyszombati egyetemtörténete (697.), Fejér Györgynek a Budára majd Pestre költözött egyetemről írt müve (381.), Mátrai Ernőnek a kolozsvári egyetemről írt könyve (902.) és Stockinger Tamás Beszéd a közmüvelödés és az egyetemekröl címü füzete (1322.). Ezeket is használhatta Pauler több egyetemtörténeti munkájához, például az 1880-ban megjelent A budapesti Magyar Királyi Tudomány-Egyetem története címủ müvéhez.

Végül említést kell tenni az egyetemes és a magyar irodalom szövegkiadásairól. Az antik görög és római szerzők jelenlétét már fentebb részleteztem. A bizánci, iszlám és a középkori európai vonatkozások teljesen hiányoznak a könyvtárkatalógusból. A reneszánsz irodalom némileg képviseltetve van, Boccaccio, Justus Lipsius és Machiavelli egy-egy müve (233., 618., 835.) révén, továbbá Kempis Tamás Krisztus követése egy francia és egy latin kiadásban az 1840es évekből (703., 1455.), valamint Shakespeare müvei német és magyar fordításban (804., 1283-1284.) szerepelnek a katalógusban. A barokk irodalomból megtalálható John Milton, Zrínyi Miklós és Esterházy Miklós egy-egy műve (928., 1615., 364.). A klasszicizmus és a felvilágosodás 18. századi irodalmából Montesquieu két (945-946.), Voltaire (967.), Rousseau (1179.), Lessing (811.) és Faludi Ferenc (374.) egy-egy müvel szerepel. A 18. századi magyar bölcselet, nyelv, történelem irodalmából Lethenyei János (812.), Kármán József (673.), Bél Mátyás (117.), Timon Sámuel (1435.) és Koppi Károly (745.) egy-egy, Pray György három (1090-1092.), és Kovachich Márton György négy müvel van képviseltetve (752-753., 755., 758.).

Goethe és kora irodalmát is kevés mü képviseli a katalógusban: Goethétől két sorozat 6 kötetben (463., 465.), Schillertől két sorozat 19 kötetben (1220 1221.), valamint Kotzebue és Walter Scott egy-egy müve (750., 1271.). A realizmus és a kortárs külföldi irodalom teljesen hiányzik a könyvtárkatalógusból. A 19. századi magyar szépirodalmat képviselik Csokonai Vitéz Mihály, Kölcsey Ferenc és Kisfaludy Károly minden munkái (260., 763., 713-714.), Jókai Mór A varchoniták címủ kisregénye (625.), Bajza József összegyüjtött munkái (79.), Petöfi Sándor versei 1845-ből (1057.), illetve Petőfi verseinek francia kiadása 1871-ből (1485.). Pauler két közeli kollégájának munkái is szerepelnek a katalógusban: a jogász és költő Császár Ferenc Öszi lombok címü verseskötete

\footnotetext{
${ }^{7}$ Vö. Buda, 2006, 540.
} 
1857-böl (254.) és a jogász, író Eötvös József három regénye (341., 346., 348.). Mindezek alapján arra következtetek, hogy Pauler latinul, németül, franciául és magyarul olvasott szívesen, angolul, olaszul feltehetően kevésbé tudott.

A könyvtárkatalógus tükrözi tulajdonosa különböző életszakaszait és világszemléletét. Megtaláljuk benne néhány ifjúkori tankönyvét, például egy 1827-es budai kiadású egykötetes Gradus ad Parnassum-ot (466.). Tekintélyes számban tartalmazta a könyvtár a jogi müveket, az országgyülés iratait, a 18. század végi szabadkőmüves könyveket és az aktuális politikai jellegü irodalmat. Összevetve Pauler könyvtárát kora újkori jogi könyvtárakkal és más 19. századi könyvtárakkal, szembeötlő az önálló szépirodalom csekély jelenléte. ${ }^{8}$ Ez nem azt jelenti, hogy a liberális katolikus ${ }^{9}$ Pauler ne olvasott volna szépirodalmat, csak az nem az 1872-es katalógusban rögzített jogi jellegü tudós szakkönyvtár része volt. A családnak bizonyosan volt könyvtára a badacsonytomaji villában is, ahol 1865-töl évtizedeken át a nyári hónapokat töltötte. ${ }^{10}$ További kutatást igényel, hogy Pauler használta-e például a Magyar Tudományos Akadémia vagy a Nemzeti Casino könyvtárát. ${ }^{11}$

Pauler naplójegyzeteiben több feljegyzésben említi olvasmányait, amelyekből kiderül a szépirodalom iránti érdeklődése és fogékonysága. Az 1838-1848 között Zágrábban tanító Pauler 1845. augusztus 26-án leírja egy kirándulását az Adriai-tengerhez: „Mi pedig 1/2 1 [órakor] elutaztunk s a szép s elég kényelmes mellékúton Delniczénél a Lujza útra lépünk; - Károlyinál egy ép azelött megölt medvének bőrét látjuk; onnan elutazván [...] Oszop mellett Ravnodolye nevü helyen elérjük a legmagasabb fokát 2936. láb a tenger fölött, majd nemsokára Jelenjénél (2785 1/2 1.) szemeim előtt az adriai tenger Kvarneri öble elterül; [...] élénken emlékszem Grünnek a tengerröl írt gyönyörü költeményére, $[\ldots]$ mélyen kedélyemre hat". ${ }^{12}$ Pauler itt minden bizonnyal Anastasius Grün német költő és politikus valamelyik versére utal. ${ }^{13}$

\section{Rezümé}

Pauler Tivadar egyetemi tanár, vallás- és közoktatásügyi, majd kétszer igazságügy miniszter és a Magyar Tudományos Akadémia tagja volt. A 19. század második felének meghatározó jogásza, élete és munkássága viszonylag jól feltárt, noha az Országos Széchényi

${ }^{8}$ Szabó Béla: Jogászaink olvasmányai a kora újkorban. = Iskolakultúra, 7. évf. 1997. 5. sz. 23-34. p. és a 4. lábjegyzetben jelzett szakirodalom.

${ }^{9}$ Pauler Tivadar ultramontánságáról: A budapesti társaság. Budapest, Pallas. 1886. 35-42. p.

${ }^{10}$ Kalmár László: Hogyan került Pauler Ákos Badacsonyba? = Badacsony, 19. évf. 5. sz. (2009. május). 6. p.

${ }^{11}$ Arany János könyvtárhaszálatáról ld. Bibor Máté János: Az Egyetemi Könyvtár Arany János kéziratai. $=$ Egyetemi Könyvtár Évkönyvei, 16. 2013. 223-248. p.

${ }^{12} 29$.f. verso.

${ }^{13}$ Pl. Am Strande, Auf dem Meere. Grün, Anastasius: Gedichte. Leipzig, Weidmann, 1841. 118-119., 154-156. p. 
Könyvtár Kézirattárában őrzött, mintegy 800 f. terjedelmü, 1845-től haláláig vezetett naplója máig kiadatlan. Lelkes könyvgyüjtő volt, könyvtárában ritka és értékes művek voltak, amelynek katalógusa fennmaradt az ELTE Egyetemi Könyvtár Kézirattárában őrzött hagyatékának dokumentumai és személyes tárgyai között. A több mint ezerhatszáz tételes könyvtárkatalógus 1872-ben készült, amikor Pauler ötvenhat éves volt. A könyvtár fö gyüjtőköre a jogi szakirodalom volt, de mutatja tulajdonosa érdeklődését a történelem, az irodalom, a szabadkőmüvesség, a vallás és az utazás iránt is.

Nemcsak a könyvtárkatalógus, hanem a könyvállomány egy része is megvan az ELTE Egyetemi Könyvtárban és más magyarországi egyetemi könyvtárakban. Az ELTE Egyetemi Könyvtárban található kötetek azonosítása nem egyszerü: egyesekben Pauler saját kezü, fekete tintával írt possessor bejegyzését találtam, másokban pedig a feltehetően a könyvtárba kerüléskor beírt ceruzás „Pauler” bejegyzés olvasható. Némely kötet korábbi tulajdonosa Zelenay János József, a nagyszombati egyetem jogi karának tanára. Más könyvek korábban a nagyszombati jezsuita kollégium tulajdonát képezték. Egy könyv korábbi tulajdonosa Caspar Gilbert Mellerstad stettfeldi plébános volt. További köteteket a „Pauler Tivadaré" bélyegzőcímke azonosít a pécsi, a szegedi és a debreceni egyetemi könyvtárban.

\section{The 1872 catalogue of Tivadar Pauler's library specialized in law}

Lawyer and university professor Tivadar Pauler held the position of Minister of Religion and Education once, and Minister of Justice twice, and he was a member of the Hungarian Academy of Sciences as well. He was one of the major lawyers of the second half of the $19^{\text {th }}$ century, his life and works have been studied sufficiently, however his diary is yet unpublished. He was an avid book collector, and left a library of rare and valuable works, the catalogue of which still exists among his documents and personal bequest in the ELTE University Library, Budapest. The library catalogue was made in 1872, when Pauler was fifty-six years old. It contains more than one thousand and six hundred books. The catalogue is dominated by the presence of law books, but shows also the interest for history, literature, Freemasonry, religion and travelling.

Not only the library catalogue, but also a part of the book collection exists in the Budapest University Library and in other university libraries in Hungary. The identification of the books available in the Budapest University Library is not easy at all: I found Pauler's handwritten possessor mark written with black ink in some books, and the mark 'Pauler' written with pencil can be read in others, probably entered when the books got to the library. Professor of the Nagyszombat University Faculty of Law, János József Zelenay was the former owner of some books. Other books were previously owned by the Jesuit College of Nagyszombat. The former owner of one book was Caspar Gilbert Mellerstad, Vicar of Stettfeld. Other books have been identified by the stamp label 'Pauler Tivadar's' in the libraries of Pécs, Szeged and Debrecen Universities.

TÜSKÉS ANNA

tudományos munkatárs

MTA BTK Irodalomtudományi Intézet 